\title{
İlköğretim Okul Bahçesi Peyzaj Uygulamalarının Eğitim Öğretim ve Öğrencilere Katkıları ${ }^{*}$
}

\author{
Hüccet VURAL ${ }^{1}$, Sevgi YILMAZ
}

ÖZET: Araşı̧ımada örneklenen okul için katılımcı yaklaşımla peyzaj tasarımı yaparak okul bahçesinde yapılan fiziki iyileştirmenin öğrencilere katkılarının belirlenmesi amaçlanmıştır. Uygulama alanı olarak Erzurum kent merkezi Yakutiye İlçesinde bulunan Mecidiye İlkokulu ve Ortaokulu seçilmiş̧ir. Araştırma peyzaj tasarım süreci, kısmi peyzaj uygulamaları ve uygulama öncesi ve sonrası anket çalışmaları sonuçlarına dayanmaktadır. Araştırma kapsamında yapılan ankete uygulama öncesi 212 öğrenci, uygulama sonrası 174 öğrenci katılmıştır. Veriler SPSS 18 programında betimsel istatistik ve Wilcoxon işaretli sıralar testi kullanılarak analiz edilmiştir. Peyzaj tasarım ve uygulama çalışmalarının yapıldığı okulda uygulama öncesi ve sonrası anket sonuçlarının karşılaştırmalı analizinde iyileştirilmiş fiziki çevrenin birçok bakımdan öğrencilere katkı sağladığı ve bu katkının istatistiksel olarak anlamlı olduğu belirlenmiştir (22 soru için Wilcoxon işaretli sıralar testi sonucu; $\mathrm{z}=-3.52, \mathrm{p}<.05$ ). Anket sonuçlarına göre okul bahçesinde yapılan peyzaj uygulamalarının; öğrencilerin memnuniyet oranına \%33.1, çevre bilinci kazanma oranına \%20.1, psikolojik olarak rahatlama oranına \%39.6, yeni şeyler öğrenme oranına \%31.1, okul başarısında artış oranına $\% 39.2$, eğitim amaçlı kullanım oranına $\% 8.7$ ve teneffüslerde çarpışma ve kazalarda azalma oranına \%28.7 katkı sağladığı belirlenmiştir.

Anahtar kelimeler: Erzurum, okul bahçeleri, okul peyzajı, tasarım süreci

\section{The Contributions of Landscape Implementations in Primary School Gardens to Education and Students}

\begin{abstract}
In this study, it was aimed to determine the contributions of physical developments in school gardens to students by designing landscape implementations for a modelled school. Mecidiye Primary and Secondary School, which are located in one of the central districts-Yakutiye, was chosen as the modelling school. The study is based on landscape implementation design process, partial landscape implementations and the data obtained from questionnaire results before and after the implementation. 212 students were attended to the questionnaire before the implementation started; and 174 students attended the questionnaire after the implementation ended. The data were analysed using descriptive statistics of SPSS 18 program and signed ranked test. According to comparative analysis of the results of questionnaires which was done by students before and after the implementation to find out contributions to students physical recruitment at schoolyard, it has been found out that more qualitative physical environment contributes to students well-being in several ways and this contribution is statistically significant (for 22 questions, the result of Wilcoxon signed rank test is $\mathrm{z}=-3.52, \mathrm{p}<.05$ ). According to questionnaire results, landscape implementations were found out to contribute to the rate of students' satisfaction at $\% 33.1$, the rate of acquiring environmental consciousness at $\% 20.1$, the rate of increase at school success at $\% 39.2$, the rate of their use for educational purposes at $\% 8.7$, and the rate of increase in accidents and crash number among students during breaks at $\% 28.7$.
\end{abstract}

Keywords: Design process, Erzurum, school gardens, school landscape

\footnotetext{
Hüccet VURAL (0000-0001-6115-1572), Bingöl Üniversitesi, Ziraat Fakültesi, Peyzaj Mimarlı̆̆ı, Bingöl, Türkiye

Sevgi YILMAZ (0000-0001-7668-5788), Atatürk Üniversitesi, Mimarlık ve Tasarım Fakültesi, Peyzaj Mimarlığı, Erzurum, Türkiye Sorumlu yazar/Corresponding Author: HüccetVURAL, huccet_vural@hotmail.com

* Bu araştırma Atatürk Üniversitesi Fen Bilimleri Enstitüsü’nde Prof. Dr. Sevgi YILMAZ danışmanlığında hazırlanan ve kabul edilen doktora tezinden üretilmiştir.
} 


\section{GíRiş}

Türkiye genç nüfusu fazla ve nüfus artışı hızlı olan bir ülkedir. Genç nüfusun fazla olması eğitim ve öğretim faaliyetlerine katılan nüfusun fazlalığını da göstermektedir. Türkiye İstatistik Kurumu Adrese Dayalı Nüfus Kayıt Sistemi (ADNSK) verilerine göre toplam nüfusun \%22.79'u örgün eğitim görmektedir (Anonim 2014). Bu nedenle eğitim ile ilgili yapılan ve yapılacak olan yatırımlar toplumun büyük bir kısmını etkilemektedir. Nitelikli insan gücünün yetiştirilmesi niteliği yüksek eğitim kurumları ile sağlanabilmektedir. Eğitim ortamlarının fiziksel ortam bakımından uygunluğu öğrenci tutum ve davranışlarının geliştirilmesi bakımından önemlidir (Karasolak, 2009). Eğitim ortamlarını oluşturan fiziki mekânların bir sistem bütünlüğü içerisinde düşünüldüğünde öğrenme süreci sağlıklı bir hal alır. Bu nedenle eğitim ortamları oluşturulurken dershanesinden laboratuvarına, koridorlarından bahçesine tüm kullanım alanlarının detaylı bir şekilde çocuğun ihtiyaçları doğrultusunda ele alınması gerekir.

Peyzaj mimarlığı mesleki disiplini içerisinde estetik ve fonksiyonel özellikler dikkate alınarak tasarlanan okul bahçelerinin ise öğrencilere, öğretmenlere, topluma ve çevreye çeşitli katkıları vardır. Okul bahçeleri uygun bir şekilde düzenlendiğinde bahçede oyun, spor, eğitim ve sosyal-kültürel faaliyetlere yönelik olanakların, çocukların birçok alanda gelişimine katkı sağladığ görülmektedir (Armitage, 2005; Algan ve Uslu, 2009; Laaksoharju et al., 2012). Aynı zamanda öğrencilerin ders aralarını geçirmeleri ve zihinlerini dinlendirmeleri nedeniyle pedagojik değerlere de sahiptir (Veitch et al., 2007). Bununla beraber okul bahçeleri yoğun yaşama alanlarında öğrenciler için rekreasyon ve oyun alanı olarak önem kazanmaktadır (Mansuroğlu ve ark., 2010; Aksu ve Demirel, 2011; Karakaya ve Kiper, 2011).

Türkiye'de okul bahçeleri ile ilgili yapılan araştırmaların fiziki yeterliliklerin belirlenmesi üzerine yoğunlaştığı görülmektedir. Okul bahçelerinin işlevlerinin belirlenmesine yönelik araştırmalarda ise yurt dıșı literatür ağırlıklıdır. Bu nedenle araştırmada örnek bir uygulama ile okul bahçelerinde yapılan peyzaj uygulamalarının öğrencilere farklı açılardan katkılarının belirlenmesi amacıyla bu araștırmaya ihtiyaç duyulmuştur. Araştırmada okul bahçesi peyzaj çalışması sonrasında öğrencilerin memnuniyet düzeyleri, eğitim amaçlı ve eğitim dışı okul bahçesinden yararlanma biçimleri, öğrenci motivasyonu, psikolojisi, çevre bilinci kazanma düzeyi gibi farklı konularda iyileşmenin olup olmadığının belirlenmesi hedeflenmiştir.

\section{MATERYAL VE YÖNTEM}

Araştırma materyalini peyzaj tasarım ve uygulama sürecinin gerçekleştirildiği Mecidiye İlköğretim Kurumu (Mecidiye İlkokulu ve Ortaokulu) oluşturmaktadır. Araştırmanın gerçekleştiği tarihlerde okul bünyesinde hem ilkokul hem de ortaokulu bulunduğu için mevzuata uygun olarak ilköğretim kurumu olarak ifade edilmiştir. Mecidiye İlköğretim Kurumu Erzurum kent merkezi Yakutiye ilçesi sınırları içerisinde yer almaktadır. Araştırmada bu okulda görev yapan yönetici ve öğretmenler ile eğitim-öğretim gören öğrencilerin görüşlerinden yararlanılmıştır. Araştırma yöntemi peyzaj tasarım süreci, peyzaj uygulama çalışmaları ve veri toplama olmak üzere üç basamakta tamamlanmıştır. Araştırmada veri toplama aracı olarak anket formu oluşturulmuş ve kullanılmıştır.

\section{Peyzaj Tasarım ve Uygulama Çalışmaları}

Örneklenen okul için katılımcı yaklaşımla peyzaj tasarımı yapılmıştır. Tasarım sürecinde öğrenci, öğretmen ve okul yöneticilerinin görüşleri alınmış elde edilen veriler ve mevcut durum analizleri doğrultusunda sörvey, leke, avan, yapısal uygulama ve bitkisel uygulama projeleri bilgisayar ortamında farklı programlar aracılığ 1 ile hazırlanmıştır. Tasarımı yapılan projenin uygulanması için Bilimsel Araştırma Projesi hazırlanmış ve yürütülmüştür (Atatürk Üniversitesi, 2012-496 nolu proje). Ayrıca proje alanında alt yapı çalışmaları Yakutiye Belediyesi tarafindan yapılmıştır. Ancak yetersiz bütçe ve imkânlar nedeniyle tasarımı yapılan projenin çok sınırlı bir kısmı alana uygulanmıştır.

\section{Anket Çalışmaları}

Örneklenen okul için peyzaj projesinin hazırlanmasında öğrenci tercihlerinin belirlenmesi ve peyzaj çalışmalarının öğrencilere ve eğitim öğretim süreçlerine katkılarının belirlenmesi için anket formu hazırlanmıştır. Anket demografik özellikleri belirlenmesinin dışında iki bölümden oluşmuştur. Birinci bölüm peyzaj tasarım süreci için veri toplama amacıyla 8 çoktan seçmeli soru, ikinci bölüm ise peyzaj uygulamalarının öğrenci memnuniyetine ve işlevselliğine katkılarını belirleme amaçlı 22 Likert ölçekli sorudan oluşmaktadır. Anket peyzaj uygulamaları öncesi ve sonrası olmak üzere iki defa yapılmıştır. Ancak uygulama sonrası anketin 
sadece 2. bölümü kullanılmıştır. Uygulama öncesi anket çalışması 14-18 Nisan 2013 tarihleri arasında, uygulama sonrası anket çalışması ise 2-6 Haziran 2014 tarihleri arasında yapılmıştır. Okul bahçesinde yapılan çevre düzenleme çalışmaları ile ikinci anketin uygulanması arasında 3-6 aylık bir süre geçmiştir. Anket çalışmasına uygulama öncesinde 217, uygulama sonrasında 174 öğrenci katılmıştır. Her iki ankete aynı grup öğrenci katılmıştır. Ancak uygulama sonrası katılım daha düşük gerçekleşmiştir. Ancak yapılan analizler ortalama değerlere dayandığ 1 için güvenirliği olumsuz etkilememektedir. Anketlerin analizinde SPSS 18 (Statistical Package for Social Sciences) paket programından yararlanılmıştır. Verilerin analizinde betimsel istatistik ve fark testleri kullanılmıştır. Örneklenen okula ilişkin uygulama öncesi ve sonrası verilerin karşılaştırmalı analizinde kullanılacak yöntemin belirlenmesi için normallik testi uygulanmış ve Shapiro-Wilk ve KolmogorovSmirnova test sonuçlarına göre tüm sorular için $p$ değeri 0.00 olarak bulunmuştur $(\mathrm{p}<.05)$. Bunun sonucu olarak dağılımın normal olmadığ 1 ve parametrik testler yerine parametrik olmayan testlerden Wilcoxon İşaretli Sıralar Testinin (Wilcoxon Signed Rank) kullanılması gereği ortaya çıkmıştır (Büyüköztürk, 2011; Duymuş ve ark., 2012).

\section{BULGULAR VE TARTIŞMA}

\section{Mecidiye İlköğretim Kurumu Peyzaj Tasarım Süreci}

Mecidiye İlköğretim Kurumu (İlkokulu) için uygulanabilir bir peyzaj projesinin elde edilmesi amacıyla tüm tasarım süreçleri izlenmiştir. Bunun için konunun ve amacın tanımlanması, mevcut durumu saptamaya yönelik veri toplama, çevre analizi, program analizi, işlev şeması, geliştirme, değerlendirme ve sentez yaparak sonuç ürünün (tasarımın) ortaya konulması süreçleri sırasıyla yapılmıştır (Yılmaz ve Yılmaz, 2000; Vural, 2002).

Tasarım süreci içerisinde örneklenen okul için alanda yapılan gözlemler sonucu sörvey ve leke çalışmaları tamamlanmıştır. Bu çalışmalar sonrasında avan proje, yapisal uygulama projesi ve bitkisel uygulama projesi hazırlanmıştır (Şekil 1).

Tasarım sürecinde kullanıcı istekleri göz önünde bulundurulmuş, en fazla tercih edilen spor alanlarına okul arka bahçesinde yer verilmiştir. Bu amaçla bir adet futbol sahas1, bir adet voleybol sahası ve iki potadan oluşan basketbol oyun alanı ile okul arka bahçesi spor alanı haline getirilmiştir. Okul arka bahçesinde spor alanının güney kısmında amfi tiyatro planlanmıştır. Amfi tiyatro spor alanları için seyirci tribünü olarak kullanılabilecek olmasının yanında çeşitli kültürel faaliyetlerin gerçekleştirilmesine olanak sunacaktır. Okul bahçesinde kısıtlı alan nedeniyle 17 araçlık otopark önerilmiştir. Otopark için yaya trafiği ile en az çakışması ve okulun en az potansiyel yarar sağlayan kısmı olan yan bahçe tercih edilmiştir. Öğrencilere bisiklet alışkanlığ kazandırılması amacıyla bisiklet park yeri de projede önerilmiştir. Okul binası girişinde tören alanı önerilmiştir. Tören alanı mevcut Atatürk büstüyle bütünleştirilmiş ve mevcut üç giriş kapısı ikiye düşürülmüştür. Tören alanında sınıf sayısı kadar yer düşünülmüş ve ön kısmında $30 \mathrm{~cm}$ yükseklik verilerek sahne önerilmiştir. Tören alanının hemen arkasında öğrencilerin teneffüs alanı olarak nitelendirilen kısmında çizgisel oyun alanına yer verilmiştir. Çizgisel oyun alanları; geleneksel ve modern oyunların oynanabildiği, çizgilerle desteklenmiş ve son y1llarda giderek okul bahçelerinde yaygınlaşan bir kullanım biçimidir.

Eğitim ve oyun amaçlı diğer bir kullanım satranç alanıdır. Ön bahçenin sol kısmında oturma birimleri ile desteklenmiş ideal ölçü olan 40x40 cm ölçülerinde satranç sahası önerisi getirilmiştir. Satranç sahası hem öğrenciler hem de öğretmenler tarafindan tercih edilmektedir. Okul yan bahçesinde satranç sahası ile birlikte spor park1, ip tırmanma, kum havuzu ve uygulama bahçesi de tasarlanmıştır. Öğrencilere fiziksel aktivite olanağ 1 sağlayan spor parkı için 6 spor aleti önerilmiştir. Çocuk uzay yürüyüşü, kondisyon bisikleti, çocuk bel esnetme, makas, twist, havada yürüyüş adlı spor aletleri ile hem teneffüsler hem de Beden Eğitimi derslerinin öğrenciler için daha zevkli geçirilmesi hedeflenmiştir. Okul bahçesi tasarımında her yaş grubu öğrencilerin ihtiyaçlarını karşılayacak düzenlemelere yer verilmiştir. Öğrencilerin bitkilerle ilgili öğrendikleri teorik bilgileri uygulamaya koyabilecekleri bir sınıflı uygulama bahçesi planlanmıştır. Öğrenciler tarafından en fazla istenilen dinlenme alanları okul bahçesinin değişik alanlarında sabit ve hareketli kullanılabilecek şekilde önerilmiştir. Bitkisel uygulama projesinde okul bahçesinde mevcut sağlıklı bitkilerin korunması ve buna ilave olarak çeşitli ağaç ve çalılar ile okul bahçesinin daha estetik görünümü sağlanmıştır. 


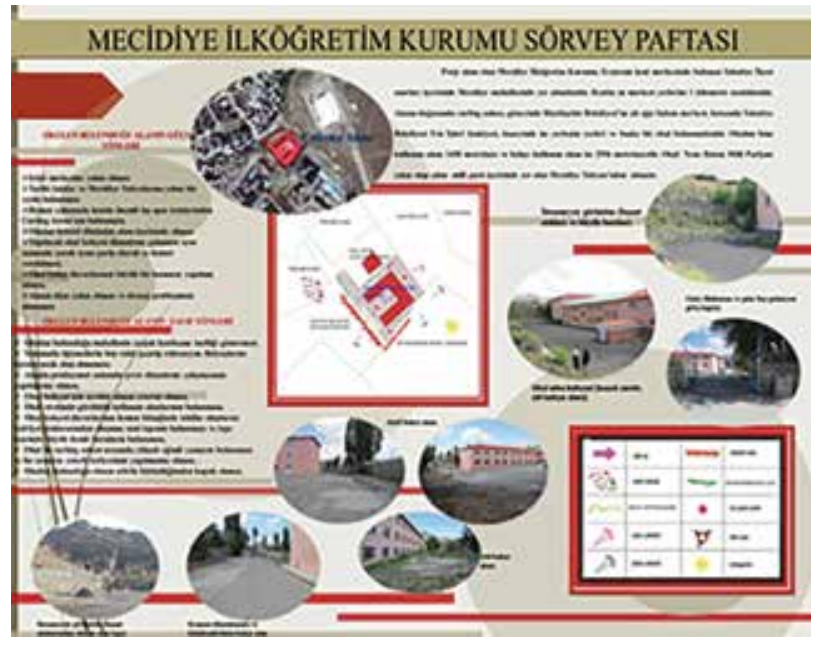

1. Sörvey paftas 1

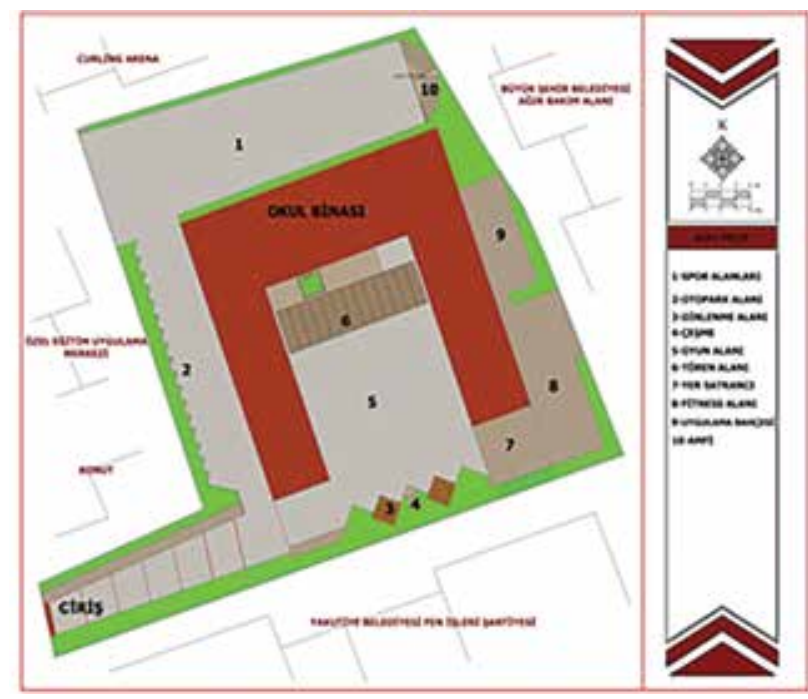

3. Avan proje

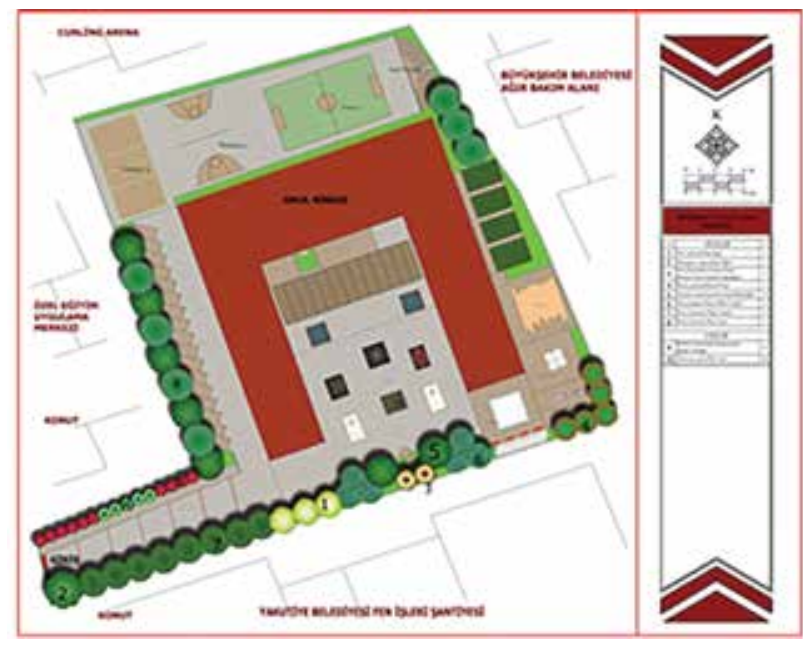

5. Bitkisel uygulama projesi

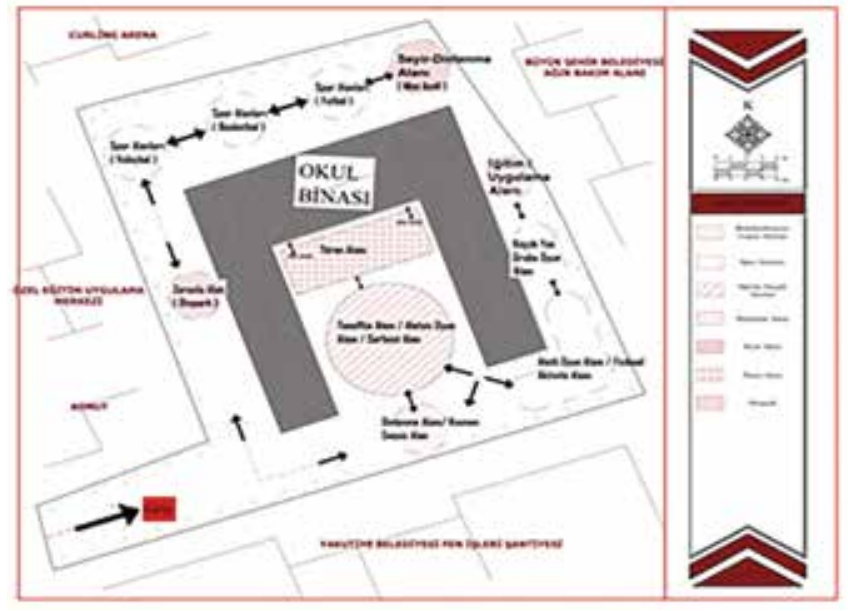

2. Leke çalışması

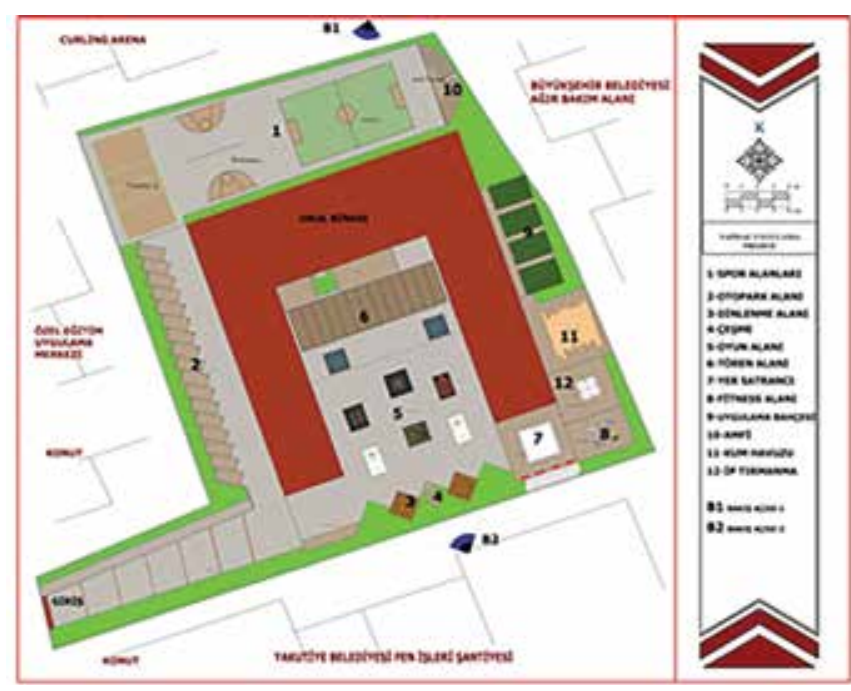

4. Yapısal uygulama projesi

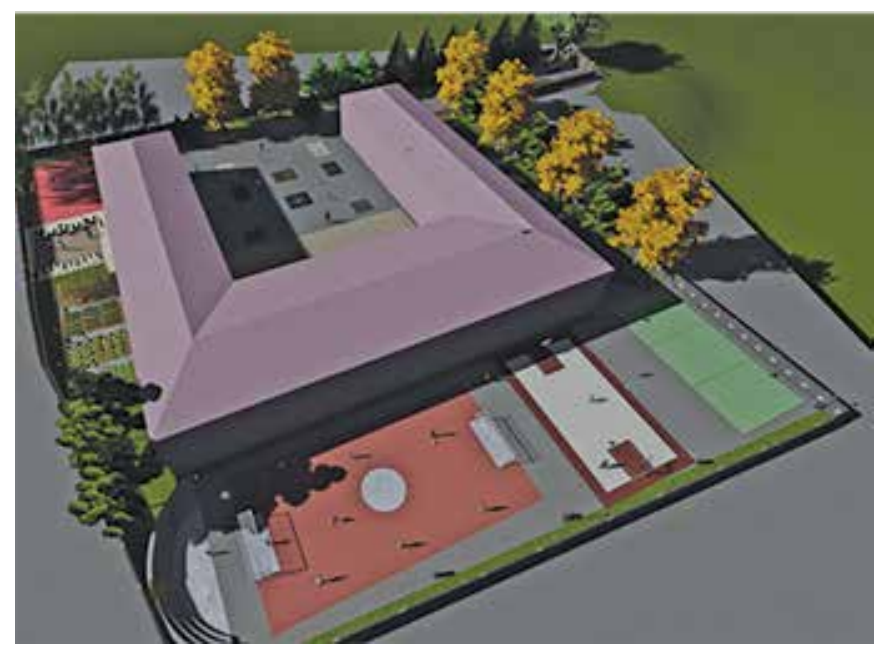

6. Üç boyutlu görünüm

Şekil 1. Mecidiye ilkokulu peyzaj tasarım süreci 


\section{Süreci}

Mecidiye İlköğretim Kurumu Peyzaj Uygulama

Projenin uygulanmasında Atatürk Üniversitesi Bilimsel Araştırma Projesi'nden sağlanan proje hibesi kullanılmıştır. Ayrıca Yakutiye Belediyesi tarafından okul bahçesinde temel alt yapı çalışmaları yapılmıştır. $\mathrm{Bu}$ nedenle tasarımın uygulanması oldukça sınırlı kalmıştır. Okul bahçesinde öncelikli olarak arka bahçede bulunan kömürlük ve merdivenler kaldırılarak okul bahçesine dâhil edilmiş ve ortalama $70 \mathrm{~m}^{2}$ alan kazandırılmıştır. Alanda temel alt yapı çalışması olarak yapılan diğer bir çalışma da arka bahçe duvarı yükseltilmiş ve yıkık olan duvarlar tamir edilmiştir. Bahçe duvarları etrafinda bulunan sorunlu alanlar nedeniyle yüksek tutulmuştur. Okul duvarları ile birlikte tretuvarlar da tamir edilmiştir. Ayrıca bahçede bulunan yıkıntılar ve gereksiz malzemeler uzaklaştırılmış ve bozuk zemin asfaltlanarak düzeltilmiştir.

Atıl durumda bulunan okul arka bahçesi spor alanı olarak tasarlanmış ve uygulanarak aktifhale getirilmiştir.
Alanda 25x15 m ölçülerinde bir adet futbol sahası, 18x9 $\mathrm{m}$ ölçülerinde bir adet voleybol sahası ve iki potadan oluşan basketbol oyun alanı yapılmıştır. Ancak yeterli alan olmadığından dolayı alan ölçüleri ve standart basketbol saha ölçüleri kullanılamamıştır. Okul ön bahçesi için tören ve teneffüs alanı tasarımda önerilmiş ve kısmen gerçekleştirilmiştir. Tören alanlarının çizimi yapılmış ve teneffüs alanına çizgisel oyun alanları oluşturulmuştur. Alana üçlü sek sek, pusula, salyangoz, kaplumbağa ve örümcek oyun alanları tasarımda önerildiği şekilde uygulanmıştır. Öğrencilerin fiziksel aktiviteye katılarak sağlıklı ve zinde olmalarını sağlamak amaciyla okul bahçesinde çocuk uzay yürüyüşü, kondisyon bisikleti, çocuk bel esnetme, makas, twist ve havada yürüyüş adlı spor ekipmanlarından oluşan spor parkı kurulmuştur. Otopark, satranç ve uygulama bahçesinden oluşan uygulamalar da tasarıma bağlı olarak kısmen gerçekleştirilmiştir. Okul bahçesinde gerçekleşen peyzaj uygulamalarına ait görünümler Şekil 2'de verilmiştir.

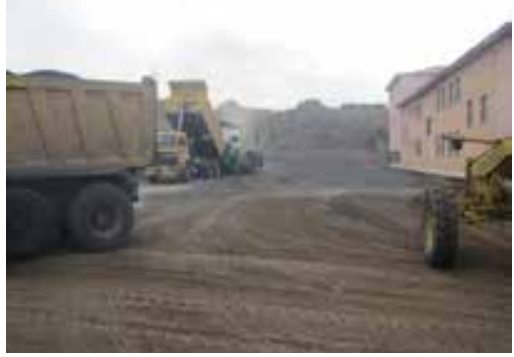

Alt yapı çalışmaları

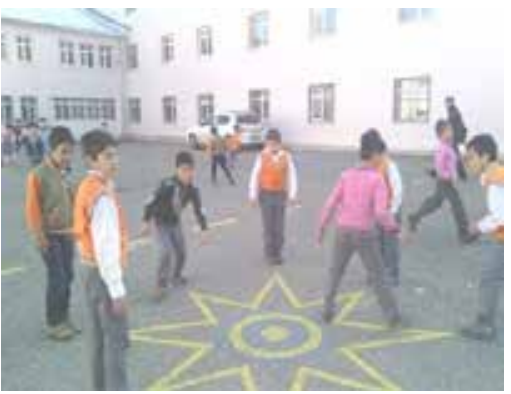

Pusula oyun alanı

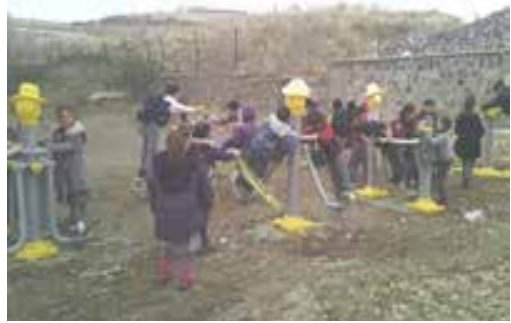

Spor parkı uygulaması

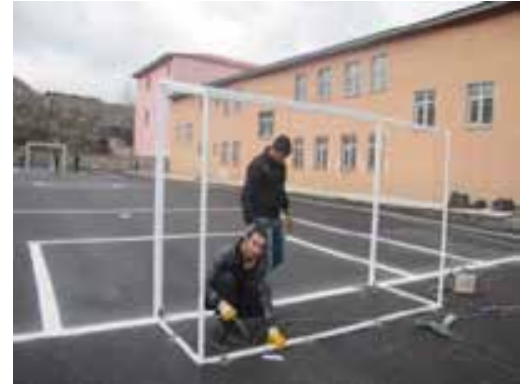

Spor alanı uygulamaları

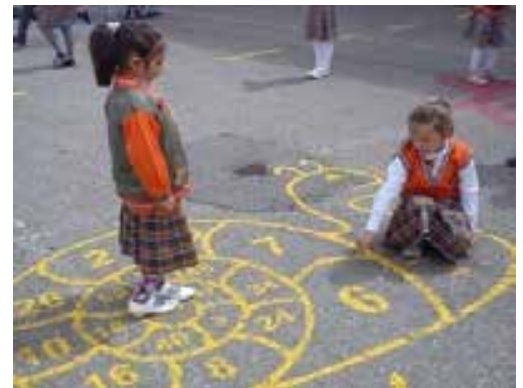

Salyangoz oyun alanı

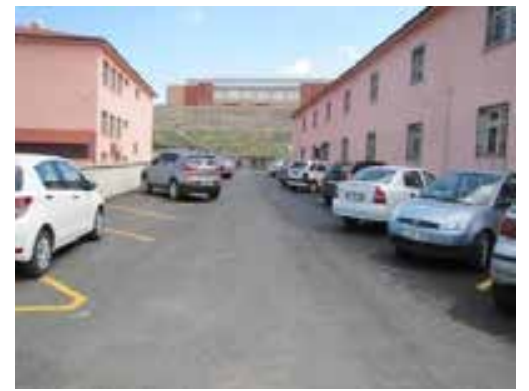

Otopark düzenlemesi

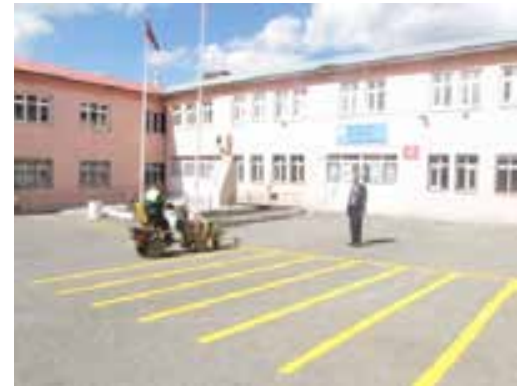

Tören alanı uygulamaları

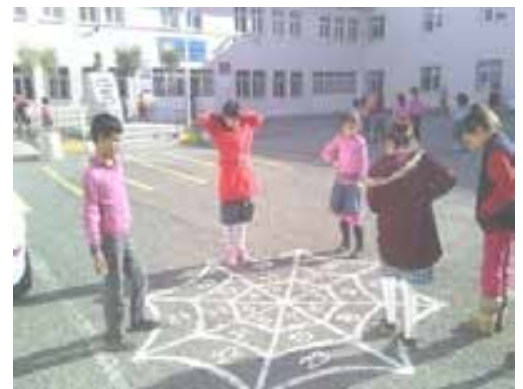

Örümcek oyun alanı

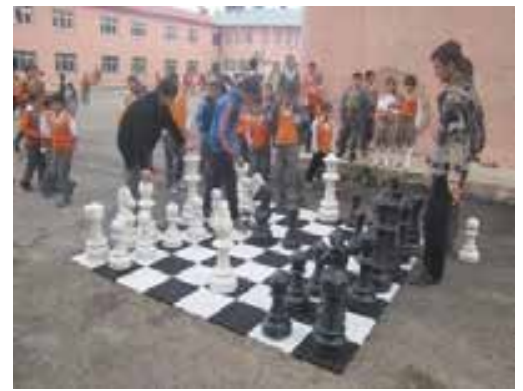

Satranç oyun alanı

Şekil 2. Okul bahçesinde yapılan peyzaj uygulama çalışmalarından görünümler 


\section{Anket Çalışmalarından Elde Edilen Sonuçlar}

Araştırma kapsamında iki aşamalı yapılan ankete katılan öğrencilerin sinıf ve cinsiyete göre dağılımları Çizelge 1'de verilmiştir. Uygulama öncesi anket çalışması okul bahçesinde her hangi bir çevre düzenleme çalışması yapılmadan önce 217 öğrenci ile uygulama sonrası anket çalışması ise peyzaj uygulamaları sonrasında 174 öğrenci ile yapılmıştır. Ankete 4.,5.,6.,7. ve 8. sınıflarda eğitim gören öğrenciler katılmıştır.

Çizelge 1. Ankete katılan öğrencilerin cinsiyete ve sınıflara göre dağılımları

\begin{tabular}{|c|c|c|c|c|c|c|c|c|c|}
\hline \multirow[t]{2}{*}{ Cinsiyet } & \multicolumn{2}{|c|}{$\begin{array}{c}\text { Uygulama } \\
\text { Öncesi }\end{array}$} & \multicolumn{2}{|c|}{$\begin{array}{c}\text { Uygulama } \\
\text { Sonrası }\end{array}$} & \multirow[t]{2}{*}{ Sinıf } & \multicolumn{2}{|c|}{$\begin{array}{l}\text { Uygulama } \\
\text { Öncesi }\end{array}$} & \multicolumn{2}{|c|}{$\begin{array}{c}\text { Uygulama } \\
\text { Sonrası }\end{array}$} \\
\hline & $\mathbf{f}$ & $\%$ & $\mathbf{f}$ & $\%$ & & f & $\%$ & f & $\%$ \\
\hline \multirow[b]{2}{*}{ Erkek } & \multirow[b]{2}{*}{96} & \multirow[b]{2}{*}{44.7} & \multirow[b]{2}{*}{82} & \multirow[b]{2}{*}{47.1} & 4.Sinif & 67 & 30.9 & 41 & 23.6 \\
\hline & & & & & 5.Sinıf & 40 & 18.4 & 49 & 28.2 \\
\hline \multirow{3}{*}{$\mathrm{K}_{1 z}$} & \multirow{3}{*}{120} & \multirow{3}{*}{55.3} & \multirow{3}{*}{91} & \multirow{3}{*}{52.3} & 6.Sinif & 51 & 23.5 & 21 & 12.1 \\
\hline & & & & & 7.Sinıf & 35 & 16.1 & 34 & 19.5 \\
\hline & & & & & 8.Sinıf & 24 & 11.1 & 29 & 16.7 \\
\hline Toplam & 217 & 100 & 174 & 100 & Toplam & 217 & 100 & 174 & 100 \\
\hline
\end{tabular}

Araştırma kapsamında hazırlanan anketin ikinci bölümü peyzaj tasarım sürecinde katılımcılığı sağlamak amacıyla yapıldığı için ilgili verilere bu kısımda yer verilmemiştir. Anketin okul bahçesinde yapılan peyzaj uygulamalarının öğrenci memnuniyetine ve okul bahçelerinin işlevlerine katkısının belirlenmesine yönelik hazırlanan 22 maddelik 5'li Likert tip ölçekli sorudan oluşan 3 . bölüme öğrencilerin verdiği cevaplar analiz edilmiştir. Buna göre uygulama öncesi ve uygulama sonrası öğrencilerin bu sorulara verdikleri cevapların ortalamaları, standart sapmaları ve değişim oranları Çizelge 2'de verilmiştir.
Uygulama öncesi ortalama değerleri ile uygulama sonrası ortalama değerleri arasında değişimler incelendiğinde tüm sorularda belirli bir değişim söz konusu olmuştur. Öğrenci memnuniyetine okulda yapılan peyzaj uygulamalarının etkisi açıkça görülmüştür. Yapılan düzenlemeler spor ve oyun alanı üzerine yoğunlaştığ için bu konuda ki sorularda değişim daha yüksek oranda gerçekleşmiştir. Ortalamalara göre değişim 0.02 ile 1.1 arasında, yüzdelik oranda değişim ise 0.6 ile 47.3 arasında gerçekleştiği görülmüştür. Örneklenen okula ilişkin uygulama öncesi ve sonrası arasında meydana gelen değişim grafiği Şekil 3'de verilmiştir.

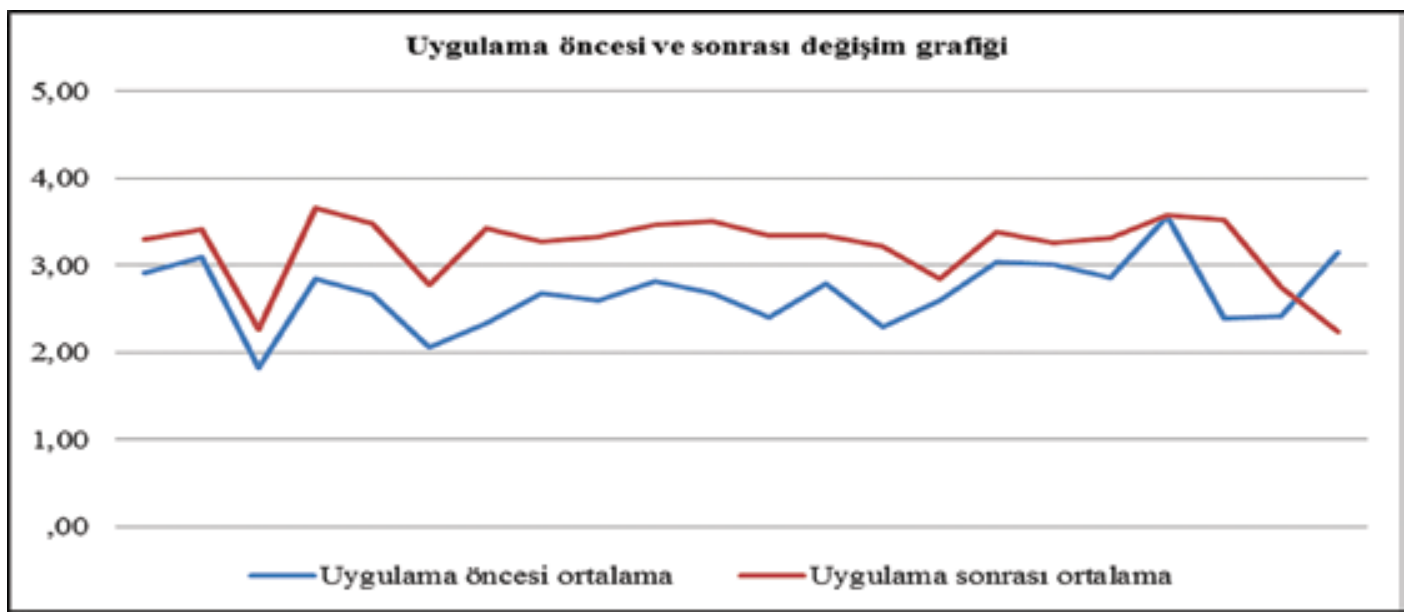

Şekil 3. Uygulama öncesi ve sonrası öğrencilerin okul bahçesinin yeterlilikleri ve işlevleri hakkındaki görüşleri değişim grafiği 
Çizelge 2. Uygulama öncesi ve sonrası ortalama, standart sapma ve değişim oranları

\begin{tabular}{|c|c|c|c|c|c|c|}
\hline & \multirow{2}{*}{ Okul Bahçesinin Yeterlilikleri ve İşlevleri ile İlgili Sorular } & \multicolumn{2}{|c|}{$\begin{array}{l}\text { Uygulama } \\
\text { öncesi }\end{array}$} & \multicolumn{2}{|c|}{$\begin{array}{l}\text { Uygulama } \\
\text { sonrası }\end{array}$} & \multirow{2}{*}{$\begin{array}{c}\begin{array}{c}\text { Değişim } \\
\text { oranı }\end{array} \\
(\%)\end{array}$} \\
\hline & & Ort. & ss & Ort. & SS & \\
\hline \multirow{11}{*}{ 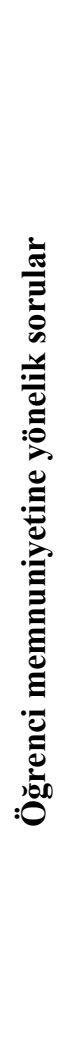 } & $\begin{array}{l}\text { Okulumuzun bahçesi; Her sınıf düzeyindeki çocuğun ihtiyacına göre } \\
\text { düzenlenmiştir. }\end{array}$ & 2.91 & 1.61 & 3.30 & 1.53 & 13.4 \\
\hline & Yeterli sayıda ağaç ve yeşil alan bulunmaktadır. & 3.09 & 1.46 & 3.41 & 1.47 & 10.4 \\
\hline & Teneffüslerde dinlenmemiz için yeteri kadar oturma birimi bulunur. & 1.83 & 1.20 & 2.26 & 1.38 & 23.5 \\
\hline & Zemin döşemesi koşma, oyun oynama ve spor yapmamıza elverişlidir. & 2.85 & 1.51 & 3.66 & 1.43 & 28.4 \\
\hline & Yeterli miktarda oyun elemanları bulunur. & 2.66 & 1.46 & 3.48 & 1.40 & 30.8 \\
\hline & $\begin{array}{l}\text { Tırmanma, atlama ve koşma gibi fiziksel etkinlikleri yapmamıza } \\
\text { uygun olarak düzenlenmiştir. }\end{array}$ & 2.06 & 1.28 & 2.77 & 1.48 & 34.5 \\
\hline & Sportif faaliyetler yapmamız için yeterlidir. & 2.33 & 1.25 & 3.43 & 1.36 & 47.2 \\
\hline & Çeşitli sosyal ve kültürel faaliyetleri gerçekleştirmemiz için uygundur. & 2.67 & 1.33 & 3.27 & 1.42 & 22.5 \\
\hline & Düzenlenirken benim de görüşüm alınır. & 2.60 & 1.59 & 3.33 & 1.51 & 28.1 \\
\hline & $\begin{array}{l}\text { Teneffüslerde bahçede koşarken başka arkadaşlarımla çarpışma } \\
\text { tehlikesi yaşıyorum. }\end{array}$ & 3.14 & 1.62 & 2.24 & 1.37 & -28.7 \\
\hline & Okul bahçemin mevcut çevre düzenlemesini beğeniyorum. & 2.39 & 1.43 & 3.52 & 1.50 & 47.3 \\
\hline \multirow{11}{*}{ 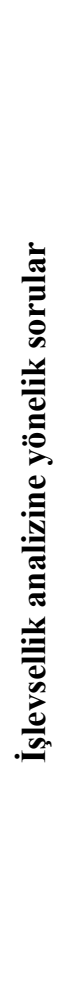 } & Sıkılmadan zaman geçireceğim bir yerdir. & 2.82 & 1.42 & 3.47 & 1.46 & 23 \\
\hline & Okulumun bahçesi yeni şeyler öğrenmeme katkı sağlar. & 2.67 & 1.50 & 3.50 & 1.58 & 31.1 \\
\hline & $\begin{array}{l}\text { Okul bahçesinin istediğim gibi bir düzenlemeye sahip olması başarımı } \\
\text { etkiler. }\end{array}$ & 2.40 & 1.38 & 3.34 & 1.45 & 39.2 \\
\hline & $\begin{array}{l}\text { Okulumuzun bahçesi çevre bilinci (yere çöp atmama, çevreye zarar } \\
\text { vermeme gibi alışkanlıklar) kazanmamıza katkı sağlayacak biçimde } \\
\text { düzenlenmiştir. }\end{array}$ & 2.78 & 1.59 & 3.34 & 1.48 & 20.1 \\
\hline & $\begin{array}{l}\text { Okulumuzun bahçesi psikolojik olarak rahatlamama katkı sağlayacak } \\
\text { biçimde düzenlenmiştir. }\end{array}$ & 2.30 & 1.241 & 3.21 & 1.54 & 39.6 \\
\hline & Okul saatleri dışında da sık sık okul bahçesinden yararlanırım. & 2.60 & 1.44 & 2.84 & 1.57 & 9.2 \\
\hline & Eğitim süresi içerisinde okul bahçesinden yeteri kadar yararlanıyorum. & 3.04 & 1.46 & 3.38 & 1.46 & 11.2 \\
\hline & Derslerde okul bahçesini kullanıyoruz. & 3.00 & 1.57 & 3.26 & 1.44 & 8.7 \\
\hline & Çevremde bulunan nesnelerin renkleri motivasyonumu etkiler. & 2.85 & 1.38 & 3.32 & 1.34 & 16.5 \\
\hline & Okul bahçesinde göze hoş gelmeyen görünümler dikkatimi dağıtır. & 3.56 & 1.46 & 3.58 & 1.45 & 0.6 \\
\hline & Çevremde olup bitenlerle ilgilenmem. & 2.42 & 1.37 & 2.75 & 1.50 & 13.6 \\
\hline
\end{tabular}


Uygulama öncesi ve uygulama sonrası değişim miktarlarının yanında bu değişimin anlamlı olup olmadığının belirlenmesi de önem taşımaktadır. Verilerin normal dağılım göstermemesinden dolayı bağımlı gruplar t-testi yerine parametrik olmayan
Wilcoxon İşaretli Sıralar Testi (Wilcoxon Signed Rank) kullanılmıştır (Büyüköztürk, 2011; Duymuş ve ark., 2012). Buna göre memnuniyet ve işlevsellik analizine yönelik 22 soru için yapılan analizde Çizelge 3'deki sonuçlar elde edilmiştir.

Çizelge 3. Tüm sorulara ait Wilcoxon Signed-Rank Testi sonuçları

\begin{tabular}{lllcccc}
\hline & $\mathbf{N}$ & $\begin{array}{c}\text { Sıra Farkları } \\
\text { Ortalaması }\end{array}$ & $\begin{array}{c}\text { Sıra Farkları } \\
\text { Toplamı }\end{array}$ & $\mathbf{Z}$ & $\mathbf{p}$ \\
\hline Uygulama Sonrası & Negatif Sıralar & $1^{\mathrm{a}}$ & 18.00 & 18.00 & & \\
Ortalama/ Uygulama & Pozitif Sıralar & $21^{\mathrm{b}}$ & 11.19 & 235.00 & -3.52 & 0.00 \\
Öncesi Ortalama & Eşdeğerler & $0^{\mathrm{c}}$ & & & & \\
& Toplam & 22 & & & & \\
\hline
\end{tabular}

a. Uygulama Sonrası Ort. < Uygulama Öncesi Ort., b. Uygulama Sonrası Ort. > Uygulama Öncesi Ort., c. Uygulama Sonrası Ort. = Uygulama Öncesi Ort.

Yapılan analiz sonucuna göre; 21 maddede uygulama sonrası ortalamalar uygulama öncesi ortalamalardan daha büyük değerlere, bir maddede ise uygulama sonrası ortalama uygulama öncesi ortalamalardan daha küçük değerlere ulaşmıştır. Elde edilen sonuçlardan 'Teneffüslerde bahçede koşarken başka arkadaşlarımla çarpışma tehlikesi yaşıyorum.' ifadesinde ortalama değerlerinde azalma görülmüştür. Toplu veriler dikkate alınarak yapılan analiz sonuçlarından; uygulama öncesi ve sonrası fark istatistiksel olarak anlamlı bulunmuştur ( $\mathrm{z}=$ $-3.52, \mathrm{p}<.05)$. Bunun sonucunda ise okulda yapilan peyzaj düzenleme çalışmalarının öğrencilerin okul bahçesinden memnuniyetlerine ve sağladığ 1 işlevlere olumlu katkı sağladığ 1 ve bu katkının önemli/anlamlı olduğu görülmüştür.

Okul bahçelerinin öğrencilere katkılarının belirlenmesine yönelik elde edilen sonuçların karşılaştırılmalı analizinden elde edilen sonuçlar ve benzer araştırmalar şu şekildedir.

1. Eğitim öğretim ortamı olarak düzenlenen bir okul bahçesi öğrencinin yeni şeyler öğrenmesine ve akademik başarısına etki etmektedir. Anket sonucuna göre yapılan peyzaj çalışmalarının öğrencinin yeni şeyler öğrenmesine katkısı \%31.1, başarıyı artırmaya etkisi \%39.2 olarak hesaplanmıştır. Dyment (2005) Toronto/Kanada'da öğretmenlerle yapılan anket ve görüşmeler sonunda ankete katılanların \%90'1 okul bahçelerinde eğitim görmenin öğrencilere coşku ve heyecan kattığını, \%72'si öğrendiği bilgilerin kalıcı olmasına katkı sağladığını, \%77'si öğrencilerin daha yaratıcı olduğunu belirterek bunun sonunda akademik başarılarının arttığını bildirmişlerdir. Ayrıca iç mekânla karşılaştırıldığında okul bahçelerinde eğitim yapmanın öğretmenlerin motivasyonlarını \%72 oranında artırdığ 1 belirtilmiştir. Fiziki çevrenin akademik başarıya etkisi üzerine çalışan Tanner (2008) dört farklı tasarım değişkenleri ile öğrenci başarısı arasında pozitif bir ilişki olduğunu, Yarbrough (2001) fiziki çevrenin 3. sınıf başarısını \%14.2, 5. sınıf başarısını ise \%9.7 oranında artırdığını, Skellly and Bradly (2000) ise iyi düzenlenmiş bir okul bahçesinin öğrenci öğrenmesini $\% 84.3$ oranında artırdığını vurgulamaktadır.

2. Uygun olarak planlanan okul bahçeleri öğrencilerin çevre bilinci kazanmaları için önemli bir fırsattır. Araştırma alanında yapılan peyzaj uygulamalarının çevre bilincine (yere çöp atmama, çevreye zarar vermeme gibi alışkanlıklar) katkısı \%20 .1 olarak gerçekleşmiştir. Bu sonuçtan hareketle fiziki ortamların uygun olması yere çöp atma, tükürme, çevreye zarar verme gibi olumsuz davranışların daha az sergilenmesine neden olduğu, bunun tersine olumsuz fiziki çevre, olumsuz davranışların meydana gelmesine etki etmektedir. Yeşil okul bahçeleri öğrencilerinin çevre yönetimi ve farkındalığını \%90, yakın çevresi hakkında bilgi edinmelerini \%91 ve çevreye karşı ilgi ve merakını ise \%92 oranında artırmaktadır (Dyment, 2005; Dyment and Bell, 2008; Bookout, 2010). Benzer bir araştırmada Skellly and Bradly (2000) iyi düzenlenmiş bir okul bahçesinin çevre eğitimini $\% 92$ 
ve deneysel öğrenmeyi \%72.9 oranında artırdığını vurgulamaktadır.

3. Okul bahçelerinin estetik ve fonksiyonel olarak düzenlenmesi öğrencilerin psikolojik olarak kendilerini rahat hissetmelerine katk1 sağlamaktadır. Okul bahçesinde her hangi bir peyzaj düzenlemesi yapılmadan önce öğrencilerin sadece \%16.6's1 bahçenin kendini psikolojik olarak rahatlamasına katk1 sağladığını düşünürken sınırlı peyzaj düzenlemelerine rağmen bu oran \%50'ye çıkmıştır. Oyun olanaklarının artışı öğrencilerin boş vakitlerini oyun ve spor aktiviteleri ile geçirerek psikolojik olarak rahatlamasını sağlamaktadır. Dyment and Bell (2007)'ye göre ise iyi düzenlenmiş okul bahçesi oyun içerisinde ögrencilerin negatif ve saldırgan davranışlarının \%66 oranında azalma meydana getirdiğini belirtmektedir. Okul bahçesinde oyun olanaklarının artması sadece psikolojik olarak rahatlamanın yanında öğrencilerin fiziksel aktivitelere daha fazla katılmalarını ve sağlıklı gelişimlerini de olumlu etkilemektedir. Teneffüslerde daha aktif olan ögrrenciler ile okula yürüyerek gelen öğrencilerin vücut kitle endeksleri düşük çıkmıştır (Özdemir ve Yılmaz, 2008; Özdemir ve Çorakç1, 2010). Dolayısıyla okul bahçelerinin obezite ile mücadelede sistematik bir sorumluluğu vardır.

4. Öğrencilerin istek ve ihtiyaçları doğrultusunda düzenlenen okul bahçeleri kullanımı artırmaktadır. Okul bahçesini sadece eğitim öğretim saatiyle değerlendirmek ekonomik değildir.

5. Araştırma kapsamında alanda gerçekleşen peyzaj uygulamaları doğal olarak öğrenci memnuniyetlerine

\section{KAYNAKLAR}

Aksu ÖV, Demirel Ö, 2011. Trabzon kenti ilköğretim okul bahçelerinde tasarım ve alan kullanımları. SDÜ Orman Fakültesi Dergisi, 12-1: 40-46.

Algan H, Uslu C, 2009. İlköğretim okul bahçelerinin tasarlanmasına paydaş katılımı: Adana örneği. Akdeniz Üniversitesi Ziraat Fakültesi Dergisi, 22(2): 129-140.

Anonim, 2014. Milli Eğitim İstatistikleri Örgün Eğitim 20132014. MEB Strateji Geliştirme Başkanlığı Yayınları, ISSN / ISBN: 1300-0993 / 978-975-11-3808-8, 262 s, Türkiye.

Armitage M, 2005. The İnfluence of school architecture and design on the outdoor play experience within the primary school. Paedagogica Historica, 41 (4): 535-553.

Bell AC, Dyment JE, 2008. Grounds for health: the intersection of green school grounds and health-promoting schools. Environmental Education Research, 14(1): 77-90. yansımaktadır. Uygulama öncesi okul bahçesinden memnuniyet düzeyleri \%27.2 olarak hesaplanmışken uygulama sonrasında bu oran \%60.3'e yükselmiştir. Memnuniyet oranında \%33.1 artış meydana gelmiş ve bu artışın oransal büyüklügü̈ \%121.69 olarak hesaplanmıştır. Ancak tasarım sürecinde önerilen tüm kullanımlar ve düzenlemelerin gerçekleşmesi durumunda yukarıda verilen tüm iyileşmelerde daha olumlu sonuçlar alınması beklenmektedir.

\section{SONUÇ}

Okul bahçelerinin öğrenciler üzerine olan farklı katkıları nedeniyle okulun diğer fiziki alanları gibi okul bahçeleri de üzerinde ciddiyetle durulması gereken ve profesyonel çalışma gerektiren bir konu haline gelmiştir. Her şeyden önce bu konularda Milli Eğitim Bakanlığı'nın gerekli yasal ve yönetsel tedbirler başta olmak üzere fiziki tedbirleri ele alması gerekmektedir. Okul bahçesi tasarım ve uygulama sürecinde öğrenci, öğretmen, yönetici ve veli gibi hedef kitlenin katılımının sağlanması gerekmektedir. Bununla beraber okul bahçelerinin planlanması, planın uygulanması, izleme, yönetme ve denetimde farklı meslek grubundan oluşan 'Okul Bahçesi Planlama ve Koordinasyon Ekibi' kurulması önerilmiştir. Planlama ekibinde peyzaj mimarı, mimar, sosyolog, pedagog, yönetici, öğretmenin bulunması gerekmektedir. Planlama esnasında öğrenci ihtiyaçları, eğitim müfredatı, okulun bulunduğu çevrenin sosyal ve çevresel durumu, öğrenci sayıs1, teknik faktörler gibi hususlar göz önünde bulundurulmalıdır.

Bookout SM, 2010. Elementary schoolyard landscapes as outdoor learning environments: North Texas stakeholders' perceptions of the no child left inside act. The University of Texas at Arlington, Master of Landscape Architecture, 127 p, USA.

Büyüköztürk Ş, 2011. Veri Analizi El Kitabı (15.Bask1). Pegem Akademi Yayınları, 216s, Türkiye.

Cengiz C, İnce ML, 2013. Farklı okul ortamlarındaki çocukların okul sonrası fiziksel aktivitelerde algıladıkları öz-yeterlikleri. Yönetim Bilimleri Dergisi, 11(21): 135-147.

Duymuş B, Yurtkoru ES, Çinko M, 2012. Sosyal Bilimlerde SPSS'le Veri Analizi. Beta Yayınları, 4.Baskı, 215s, Türkiye.

Dyment JE, 2005. Gaining Ground: The Power and Potential of School Ground Greening in the Toronto District School Board. National Library of Canada Cataloguing in Publication Data, ISBN 0-9732124-9-7, 53s, Canada. 
Dyment JE, Bell AC, 2007. Active by design: promoting physical activity through school ground greening. Children's Geographies, 5(4): 463-477.

Hodson CB, Sander HA, 2017. Green urban landscapes and schoollevel academic performance. Landscape and Urban Planning, 160: 16-27.

Karakaya B, Kiper T, 2013. Edirne kent merkezindeki bazı ilköğretim okul bahçelerinin peyzaj tasarım ilkeleri açısından mevcut durumunun belirlenmesi. Tekirdağ Ziraat Fakültesi Dergisi, 10 (1): 59-71.

Karasolak K, 2009. Mimari özellikleri farklı ilköğretim okullarındaki öğrenci ve öğretmenlerin okullarının bina ve bahçeleri hakkındaki görüşlerinin incelenmesi. Çukurova Üniversitesi Sosyal Bilimler Enstitüsü, (Basılmamış) Yüksek Lisans Tezi, 168s.

Laaksoharju T, Rappea E, Kaivolab T, 2012. Garden affordances for social learning, play and for building nature-child relationship. Urban Forestry \& Urban Greening, 11: 195- 203.

Li D, Sullivan WC, 2016. Impact of views to school landscapes on recovery from stress and mental fatigue. Landscape and Urban Planning, 148:149-158.

Mansuroğlu S, Sabancı A, Erdoğan R, 2010. İlköğretim Okulları Bahçelerinin Eğitimsel Etkinlik ve Öğrencilere Katkılarının Değerlendirilmesi: Antalya Örneği. TÜBİTAK-ÇAYDAG, Proje No: 107Y306, Sonuç Raporu (Basılmamış), 159 s., 2010.

Matsuoka RH, 2010. Student performance and high school landscapes: Examining the links. Landscape and Urban Planning, 97: 273-282.
Özdemir A, Y1lmaz O, 2008. Assessment of outdoor school environments and physical activity in Ankara's primary schools. Journal of Environmental Psychology, 28(3): 287300 .

Özdemir A, Corakçı M, 2010. Participation in the greening of schoolyards in the Ankara public school system. Scientific Research and Essays, 5 (15): 2065-2077.ö

Skelly SM Bradley JC, 2000. The Importance of school gardens as perceived by Florida elementary school teachers. Hort Technology, 10(1): 229-231.

Tanner CK, 2008. Explaining relationships among student outcomes and the school's physical environment. Journal of Advanced Academics, 19( 3): 444-471.

Veitch J, Salmon J, Ball K, 2007. Children's perceptions of the use of public open spaces for active free-play. Children's Geographies, 5(4): 409-422.

Vural H, 2002. Tarihi çevrelerde peyzaj planlama ve Erzurum kenti örneği. Atatürk Üniversitesi Fen Bilimleri Enstitüsü, (Basılmamış) Yüksek Lisans Tezi, 127s.

Yarbrough KA, 2001. The relationship of school design to academic achivement of elemantary school children. Department of Educational Leadership University, (Basılmamış) Doktora Tezi, 114s.

Yılmaz H, Yılmaz S, 2000. Peyzaj Mimarlığında Tasarım Süreci ve Proje Örnekleri. Atatürk Üniversitesi Ziraat Fakültesi Ders Yayınları, No: 218, 106s, Türkiye. 